\title{
" Infrastructure and nation building: The regulation and financing of network transportation infrastructures in Spain (1720-2010)"
}




\section{$\bigoplus_{\circledast}|| R|E| A \mid$}

Institut de Recerca en Economia Aplicada Regional i Pública

Research Institute of Applied Economics

\section{Universitat de Barcelona}

Av. Diagonal, $690 \bullet 08034$ Barcelona

WEBSITE: www.ub.edu/irea/•CONTACT: irea@ub.edu

The Research Institute of Applied Economics (IREA) in Barcelona was founded in 2005, as a research institute in applied economics. Three consolidated research groups make up the institute: AQR, RISK and GiM, and a large number of members are involved in the Institute. IREA focuses on four priority lines of investigation: (i) the quantitative study of regional and urban economic activity and analysis of regional and local economic policies, (ii) study of public economic activity in markets, particularly in the fields of empirical evaluation of privatization, the regulation and competition in the markets of public services using state of industrial economy, (iii) risk analysis in finance and insurance, and (iv) the development of micro and macro econometrics applied for the analysis of economic activity, particularly for quantitative evaluation of public policies.

IREA Working Papers often represent preliminary work and are circulated to encourage discussion. Citation of such a paper should account for its provisional character. For that reason, IREA Working Papers may not be reproduced or distributed without the written consent of the author. A revised version may be available directly from the author.

Any opinions expressed here are those of the author(s) and not those of IREA. Research published in this series may include views on policy, but the institute itself takes no institutional policy positions. 
Abstract

This paper analyzes Spanish infrastructure policy since the early 1700s: Road building in the eighteenth century, railway creation and expansion in the nineteenth, motorway expansion in the twentieth, and high speed rail development in the twenty-first. The analysis reveals a long-term pattern, in which infrastructure policy in Spain has been driven not by the requirements of commerce and economic activity, but rather by the desire to centralize transportation around the country's political capital. As commerce has been unable to sustain the development of this policy, regulation and subsidies from the national budget have regularly been used to decide the priorities regarding infrastructure creation and to fund the development, maintenance, and operation of the networks.

JEL classification:. L91, L92, L98.

Keywords: Infrastructure, Transportation, Railroads and Other Surface Transportation, Government Policy

Germà Bel is Professor at Universitat de Barcelona and Guest Professor at Barcelona Graduate School of Economics. Departament de Política Econòmica. E-mail: gbel@ub.edu.

\section{Acknowledgements:}

This research has received financial support from the Spanish Ministry of Science and Innovation (ECO2009-06946/ECON), and from the Autonomous Government of Catalonia (SGR2009-1066). I have benefited from comments by Daniel Albalate, Joan Calzada, Judith Clifton, Xavier Fageda, Alfonso Herranz, Pedro Pablo Ortúñez, Ramon Perelló, and Emili Rosales. Comments received through the editorial process have been extremely helpful. 


\title{
Infrastructure and nation building: The regulation and financing of network transportation infrastructures in Spain (1720-2010)
}

\begin{abstract}
"When high roads, bridges, canals, etc. are in this manner made and supported by the commerce which is carried on by means of them, they can be made only where that commerce requires them, and consequently where it is proper to make them. Their expense too, their grandeur and magnificence, must be suited to what that commerce can afford to pay. They must be made consequently as it is proper to make them. A magnificent high road cannot be made through a desert country where there is little or no commerce, or merely because it happens to lead to the country villa of the intendant of the province, or to that of some great lord to whom the intendant finds it convenient to make his court.”
\end{abstract}

Adam Smith, The Wealth of Nations, (1776, vol. III.V.I, pp. 95-96).

At the end of 2010, Spain has the largest High Speed Train network in Europe and the second largest in the world after China. Nonetheless, HST passengers in Spain represent only about $6 \%$ of those in Japan, and about 15\% of those in France. As far as airports are concerned, Spain is the only relatively large EU country with a large air market where ownership and management are strictly public and centralized, recalling communist models. Spain’s motorway policy is singular as well: the financing model is hybrid, with $25 \%$ of the network tolled and 75\% toll-free, with a sharp territorial asymmetry in the distribution of tolls throughout the country. These distinctive characteristics of Spain's transport infrastructures are the result of a long term policy that has used infrastructure for nation building rather than as a tool for creating a transportation system able to foster productivity and economic growth.

Centralization of transport infrastructure, and particularly that of the railway systems, has received some attention in the literature, particularly in works on the history of transportation in Australia. ${ }^{1}$ The centralization of state railways in Australia has been extensively studied in Wotherspoon (1979), Docwra and Kolsen (1989), and more recently Gray (2009), who concludes that this centralization emerged from the political desire to establish and maintain territorial control in the form of a hierarchical governmental and administrative system managed from capital cities. Other cases of centralization, such as that of Argentina, seem to be more the result of the development of private industry, with no deliberate desire on the part of the central government to maintain control over it (Fleming, 1991). ${ }^{2}$

This paper studies whether the radial design of surface transportation networks around Spain's capital city, Madrid, reflects a deliberate desire of the central government. We analyze the infrastructure policy implemented in Spain since the early 1700s: road building in the eighteenth century, railway creation and expansion in the nineteenth, motorway expansion in the twentieth, and high speed rail development in the twenty-first. Our study contributes to the literature in several ways. First, the analysis is undertaken at nation-wide level. Second, we adopt a long-term perspective, which allows us to trace the centralization pattern back to

\footnotetext{
${ }^{1}$ The effects of the radial railway network in the nineteenth century in Spain have been discussed in Nadal (1975) and Casañas Vallés (1977). However, they do not specifically discuss the issue of centralization.

${ }^{2}$ The early development of telegraphic communication systems was primarily driven by military purposes in most countries, (Flichy, 1995, pg. 19). France was an outstanding example of this trend, which resulted in a highly centralized network. However, the initially centralized design of the French network was soon seen as inefficient, and from the early 1830s on junction lines were built in the French telegraph network, so that a 'multi-connection' network could be created (Flichy, 1995, p. 30).
} 
the period preceding the first railway extension. Third, and more importantly, we analyze network regulation and financing as the main tools used by government policy to centralize the surface infrastructure networks.

Our analysis reveals a long-term regularity: infrastructure policy in Spain has not been driven by the requirements of commerce and economic activity, but rather by the desire to centralize transportation around the political capital of the country. Because commerce could not sustain the development of such a policy, regulation and subsidies from the national budget have regularly been used to decide the priorities regarding infrastructure creation and to fund the development of the networks.

Summing up, this paper explains why national policies on regulation and financing of transportation infrastructure in Spain are unique among the developed countries. Starting in the eighteenth century, we see that transportation policy in Spain has been driven by a philosophy of nation building rather than by the needs of economic activity, and that centralization has been the main driver of this policy.

\section{Spain after the War of Succession: Building a country like France, and a capital like Paris}

Carlos II, the last king of the Hapsburg dynasty, died in 1700 and was succeeded by Philippe de Bourbon, Duke of Anjou and grandson of Louis XIV, the Sun King, who would reign in France until 1715. The new monarch, now known as Felipe V, arrived in Madrid in January 1701, and reorganized both the court and the government in accordance with French models. As Elliott (1963) points out, Spanish government offices now mimicked their French counterparts and leading governmental positions were awarded to Frenchmen brought to Madrid by the new king.

Shortly after the accession of Felipe V in 1702 the War of the Spanish Succession broke out, as the Austrian Empire fought to regain its right to the throne. This war began as an international conflict, but it also acquired an internal dimension, since the territories of Castile and Navarre aligned with the French party while the territories of Aragon supported the Austrians. The war, which "took the form of a Bourbon conquest of Catalonia, Aragon and Valencia” (Ringrose, 1966, p. 139), came to an end in 1714/1715, with the consolidation of the new Bourbon dynasty.

During the course of the war, the first decree of the Nueva Planta was passed in June 1707, which abolished the institutions of the Valencia and Aragon Kingdoms and reorganized the judiciary introducing the ruling of Castilian courts. Soon after the end of the war, two decrees were published in November 1715 and January 1716, the first concerning the Balearic Islands and the second Catalonia, which reorganized the judiciary as well, and imposed the use of Castilian as the official language in administration. The monarchy also took control of the taxing system in the territories of the Aragon Crown. This move eased the pressure on the state's finances, together with the reduction of expenditure brought about by the loss of Italy and the peace with Holland after the Treaty of Utrecht in 1713. In the institutional area,

"local Courts were abolished, the Crown started to sell off the alderman positions in the municipal Councils, the courts joined the Castilian system and the mayors (corregidor) were appointed from 
Madrid. In this way, not only was royal authority strengthened in Castile, but Castilian practices were extended to the Crown of Aragon” (Ringrose, 1994: p.296).

Spain was transformed de iure and de facto into a centralized state (Elliott, 1963). The centralist and 'Castilian' orientation of the new dynasty, which had already been evident since Felipe V's accession to the throne, was accentuated after the war. The new dynasty had come from France and adopted the French model as a reference in the planning of power. Like Paris in France, Madrid became the capital of a state in which the political power was monopolized by central institutions. From that moment on, the project of turning Spain into France, and Madrid into a capital like Paris, gathered pace. As explained in Álvarez Junco (2001, pp. 102103): "the idea was to imitate the French model... This meant reconstructing the Armada, centralizing the administration, improving the roads... What was good for the monarchy was good for Spain. And what had strengthened the French monarchy would benefit the Spanish one as well”.

The new plan met with little opposition; Castile's elite saw the decision to follow the French administrative and cultural model as a way to strengthen the political organization of the monarchy and to redress the country's decline (Lluch, 1996, p. 122). Borja de Riquer (1994) notes that the political elite opted to unite and centralize as a way of establishing a nation. In short, Bourbon reformism was the adaptation of French reformism in Spain (Vicens Vives, 1952), and from that time onwards the French influence was omnipresent.

\section{Road policy in the eighteenth century Spain: The birth of the radial State}

The road network of Hapsburg Spain had its origins in the Roman network of the third-fourth centuries. It presented some of the basic characteristics of mesh connections and formed a decentralized network (Madrazo, 1984, pp. 27 and 151-152), which was much less dense in the northwest of the peninsula (Galicia and Asturias) and in the southwest part of the central plateau or Meseta (Villuga, 1546). This network was characterized by itineraries from east to west that ran through the large river valleys, routes from north to south linked to the east-west ones, and some diagonal routes that also connecting them to the roads above (Uriol, 1985, p. 556-557). In essence, this is the map of the roads inherited by the Bourbon dynasty at the beginning of the eighteenth century.

After the consolidation of the new dynasty's political power, the reform of the communications system was undertaken. The postal service, which had been contracted out to private interests since the sixteenth century, was reformed. In 1716, Felipe V completely internalized the service, which was to be provided directly by the Crown. Likewise, "as part of the centralizing policy of the Bourbons... who undertook the construction of a modern road network in Spain funded by the Treasury of the Crown” (Uriol, 1977, p. 837). The bases of this process were legally established in the Reglamento General para la Dirección y Gobierno de los Oficios de Correo Mayor y Postas de España, en los viajes que se hicieren, approved on 23 April 1720. The regulation introduced the Relación de las Carreras de Postas (List of the King's Highways), indicating the origin and destination of each journey. The list set up a radial network based on Madrid, going to (1) Bayonne, via Pamplona and Irun; (2) to Barcelona and the French border; (3) to Valencia; (4) to Murcia and Cartagena; (5) to Cadiz via Seville; (6) to Badajoz; and (7) to Galicia via Medina del Campo (with a branch towards Salamanca). The network was completed by a parallel road along the Mediterranean between Barcelona and Alicante (with a link to Teruel), another parallel to the Portuguese border, 
between Benavente and Seville, and the connection between Burgos and Medina del Campo, via Valladolid. The King's Highways are shown in the map below.

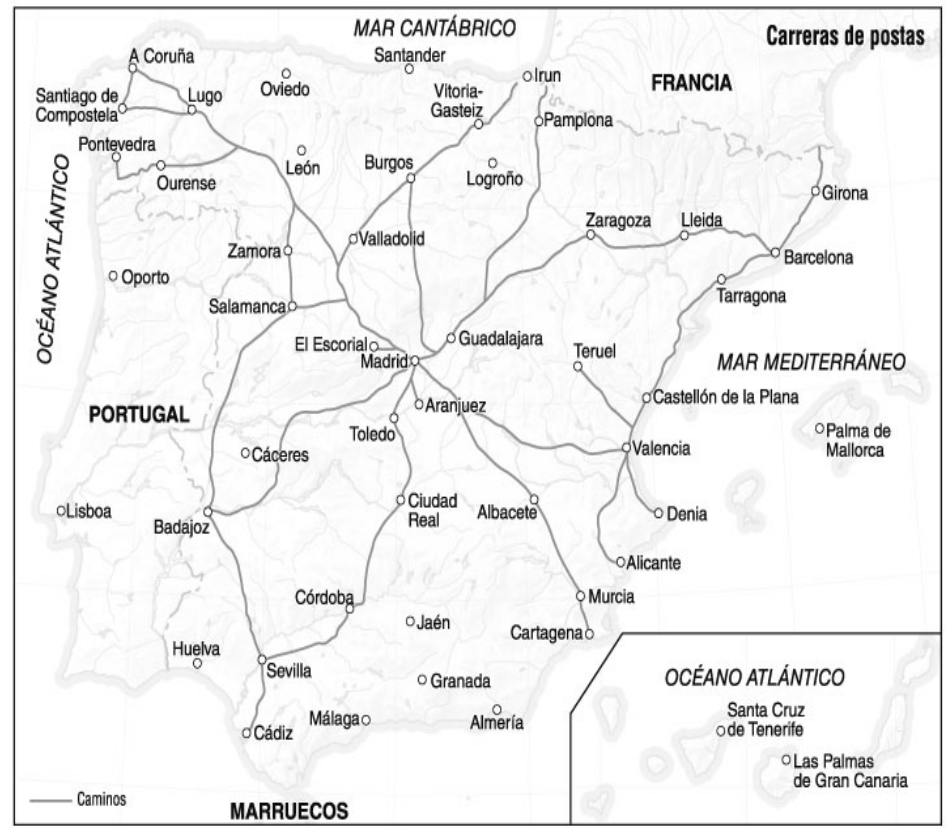

Map 1: The King’s Highways defined in 1720

The network was mainly designed to facilitate the dispatch of orders from the Court and the transmission of information to the capital, and it established a radial system that has remained unaltered until today.

Following the tradition established after the end of the Roman Empire, the building and maintenance of the highways were the responsibility of the municipalities, which had to bear the costs of a process that was authorized by the Crown. This funding system turned out to be unable to achieve the objectives sought by the Crown for the King's Highways; the limited trade traffic did not generate sufficient revenues for municipalities to cover the costs of their investment. Therefore, in 1747 Fernando VI issued a Real Cédula (Royal Decree) which raised for the first time the possibility of building the King's Highways with funding from the Crown's Treasury (Uriol, 1978, p. 535). Thus, for the first time in the history of Spain, the state assumed direct financial responsibility for road construction.

The Tratado legal y político de caminos públicos y posadas (Fernández de Mesa, 1755) explicitly proposed that the cost of the creation of King's Highways should be covered by the Crown, and that the rest of the roads (though not the radial ones) should be financed by those 
who benefited from them, mainly the municipalities. Road building was extensively financed by the Treasury during the reign of Carlos III, who came to the throne in 1759. Indeed, in 1761 a general road plan was introduced, inspired by Bernardo Ward's recommendations written in 1760 (and later published in 1762). Ward's work defined six basic radial roads, coinciding with the radial King's Highways in the 1720 Regulation: "Spain needs six big roads, from Madrid to Corunna, to Badajoz, to Cadiz, to Alicante, and to the French border, through Bayonne and through Perpignan; and from these, other roads must go to several sea Ports and other main cities” (Ward, 1762, p. 55).

Ward urged that the building of these large roads should be funded by the Treasury. His proposals were included in the Decree issued on 10 June 1761, which included specific Treasury funding for the roads from Madrid to Andalusia, Catalonia, Galicia and Valencia (Menéndez Pidal, 1951, p. 123). To finance these roads a national salt tax was instituted, initially for twenty years, then successively extended until 1801. This was the funding mechanism for the radial road network.

Thus, the map of the King's Highways instituted by Felipe V was consolidated as the radial road map of Spain by means of the 1761 decree, which established the six core axes with their six main roads. Gómez Mendoza (2001, p. 349) describes the reasons behind this design as follows: "By means of a network of this type, the Bourbon legislators sought to satisfy administrative objectives (post and information), military, and of public order (the supply of goods to Madrid). They ignored purely economic objectives”. In fact, the question of efficiency and the contribution of the transport system to productivity and the economy were neglected in favor of administrative and political objectives (Madrazo, 1984, pp. 62-63 and 159). Political and government interests were the priority, and a model was born that would become permanent in Spain. ${ }^{3}$

\section{The establishment and development of the railway in Spain}

\section{Early days}

After the failure of the initial rail projects in 1820 and the 1830s, the first successful railway concession was the one awarded in 1843 for a line of $28.5 \mathrm{~km}$. between Barcelona and Mataró, promoted by private interests that expected freight traffic to provide the major part of the demand (at this time the possibility of transporting passengers was barely considered). Shortly afterwards, in 1845, the Marquis of Salamanca was awarded a line between Madrid and Aranjuez, covering $49 \mathrm{~km}$. Work on this line started in 1846, but was interrupted at the end of 1847 due to financial difficulties. In contrast, the Barcelona-Mataró line, which had received no public support, was completed and opened on October 28, 1848, becoming the first operating railway in Spain. ${ }^{4}$ Work on the Madrid-Aranjuez line recommenced after obtaining funding from the Treasury, and the line was finally inaugurated on February 9, 1851.

Other stretches of railway were built in those early years. The Xativa-Valencia line, covering 57 km., opened in 1854; the mining line Sama de Langreo-Gijón, was completed in 1856. In

\footnotetext{
${ }^{3}$ Note as well that on 16 January 1769 a Royal Order was issued establishing that distances in each road would be counted from Madrid. This constitutes the historical origin of the 'kilometer zero', which still exists in Spain.

${ }^{4}$ It is worth noting that the first operating railway in Spanish territories was that between La Habana and Güines, in Cuba, which began service in 1837 (de Diego García, 1983).
} 
Catalonia the railway expanded rapidly (Pascual Doménech, 1999, pp. 91-94), with lines linking Barcelona with Granollers and Molins de Rei (and its extension to Martorell), and the stretch between Sabadell and Montcada which linked up with the Barcelona-Granollers line. Most of these first lines reflected a real interest in exploiting the existing road traffic flows (Comin Comin et al., 1998, p. 41), with the exception of certain lines, such as the one from Madrid to Aranjuez and then to Albacete, which had been financially guaranteed by the state, thus violating the current legislation.

\title{
The genesis of the radial railway in Spain: the Railways Parliamentary Committee of 1850.
}

In the mid-nineteenth century, government involvement in railway expansion increased. After an initial failed attempt by the Minister Bravo Murillo in 1847 to pass a General Railway Act, the project was taken up again in 1850 by the Minister Seijas Lozano. His plan was appraised that year by a Congressional Committee (the Olózaga Committee, named after its chairman). The fundamental objective of the planned network was to link the political capital with the maritime periphery, according to Mateo del Peral (1978, p. 56), because "The members of the commission, who resided in the capital, saw secondary railways arising with partial routes, which aimed to link close centers of production, normally within the same provincial area, while Madrid remained relatively isolated and in danger of accentuating its isolation.”

Among all the points considered by the Commission, we are particularly interested in the decisions on the shape of the network and the choice of the priority routes. In agreement with the government, the Commission tried to establish and subsidize a number of main routes at the public treasury's expense: (1) from Madrid to Bayonne, with branches to the major ports of the north and northeast, and one from Valladolid in the direction of Porto, (2) from Madrid to Cartagena, with branches to Alicante and Valencia, (3) from Madrid to Barcelona via Zaragoza, (4) from Madrid to Lisbon through Extremadura, and (5) from Madrid to Cadiz as a continuation of the Lisbon line or a branch of the one to Cartagena (Congreso de los Diputados, 1850, p. 161).

The testimony of prominent military men, engineers and financiers provide valuable information ${ }^{5}$ regarding the criteria adopted for the railway development. For example, General Laureano Sanz emphasized the importance of supplying the capital: "the lines that I consider best for the prosperity of the country are those that connect the capital of the monarchy with the Ocean and the Mediterranean; i.e. the ones that can bring anything necessary to the center of the monarchy"(Congreso de los Diputados, p.164). Mr. Mazarredo also agreed that railway lines should start from Madrid because:

\begin{abstract}
"The situation of the capital of the Monarchy in Madrid places the city at a certain disadvantage as the area and the surroundings are lacking many of the elements that allow capitals great development in other nations. Madrid is not a producer, but it finds itself in possession of the capital status; and without great public disruption this cannot be changed... Thus, the rest of Spain should compensate the advantage of not being subjugated by Madrid. Madrid, as a capital, has great needs; and these are not covered by its own production; so it is necessary that the producer should meet these needs in order to supply to this point the foodstuffs and the basic products which are consumed in so much abundance." (Congreso de los Diputados, 1850, p.165)
\end{abstract}

\footnotetext{
${ }^{5}$ The opinions expressed and recommendations made are available in Información parlamentaria hecha por la Comisión de Ferro-carriles nombrada por el Congreso de los Diputados en 10 de enero de 1850.
} 
Another influential soldier, Brigadier Buenaga, completed the argument in favor of a radial network stating that "the Madrid of 1808 was not the Madrid of 1850; since that time, many of the provincial antipathies have been calmed, power has been centralized, political constitutions have been transformed and have given new fuel and vigor to the State, the Court has visibly gained in importance, and it is and will be, for a long time at least, the strategic political point” (Congreso de los Diputados, 1850, p. 190). The justification of the grounds for a radial design with Madrid in the center had been established. The issue was resolved by the Commission, with just one main change: the elimination of the line from Madrid to Barcelona via Zaragoza, which, as far as the supply of the capital was concerned, was considered to be of minor interest.

\section{Railway development and legislation: The Acts of 1855, 1870 and 1877.}

The first Railways Act, 1855, took as its basis the priority lines of the 1850 Commission, recovering the Madrid-Barcelona line via Zaragoza, and adding the extension to Malaga of the Cadiz line, the extension to the Galician coast of the line to Valladolid and the connection between Zaragoza and the Madrid-Irun line. These lines are shown in map 2. This is how the radial design of the railway system was established, since these were the priority lines which would benefit from state promotion and subsidies.

The railway policy adopted in Spain differed significantly from other European experiences where commercial interests were the driving factor of the railway network extension, such as the United Kingdom (Hawke \& Higgins, 1983), Belgium (Derry \& Williams, 1960), Germany (Fremlindg, 1983), and Italy (Fenoaltea, 1983). In some aspects, the Spanish policy resembled the policy carried out in France, especially in terms of the choice of the model of concession to the private sector with strong support from the public treasury. The main lines would be built at the state's expense; i.e. with guarantee of full recovery of investments and profitability. But while in 1838 the French parliament had rejected a plan to create a radial network emanating from Paris (Caron, 1983, p. 29), ${ }^{6}$ the Spanish Congress approved the construction under the state's guarantee of a radial network with its center in Madrid.

\footnotetext{
${ }^{6}$ The way in which radial and transversal lines were combined in the development of the French network can be seen in Dunham (1941).
} 


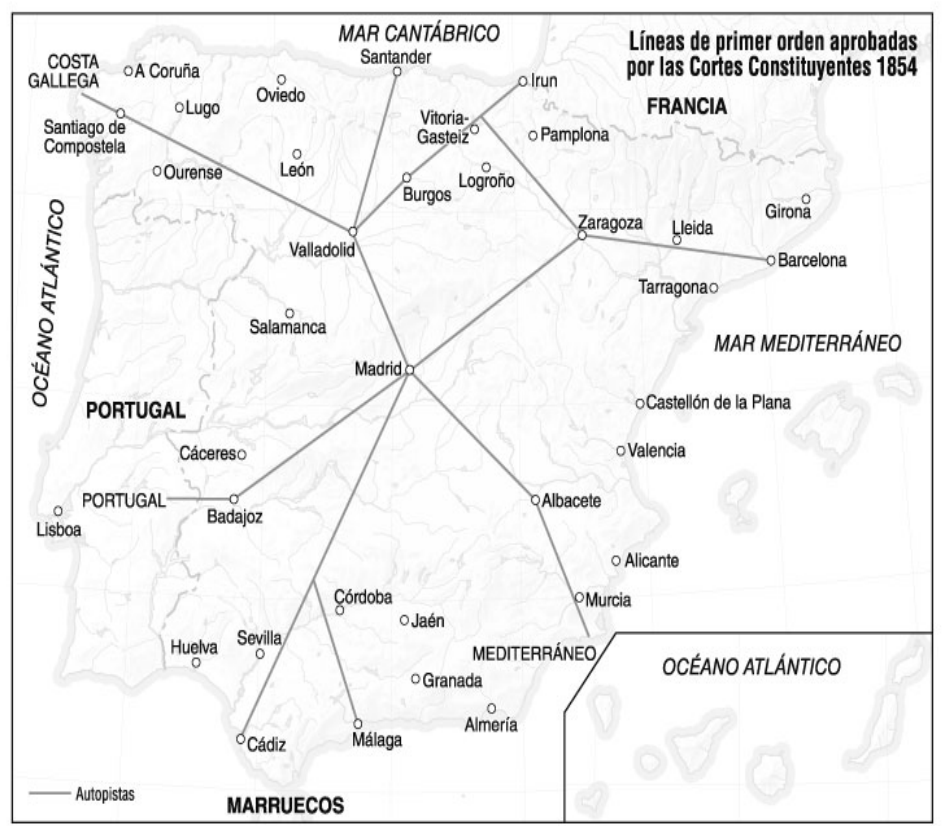

Map 2: Priority lines approved by the Spanish Parliament in 1855.

With the passing of the 1855 Act, the railway expansion gathered momentum apace. Between 1855 and the end of the 1860s almost $6300 \mathrm{~km}$ were granted; together with the $1100 \mathrm{~km}$. granted prior to 1855, the total figure amounted to $7363 \mathrm{~km}$. However, not all the lines that were granted were actually built.

In 1864, the preliminary report for a new General Railway Plan, drawn up by a committee of engineers appointed by the Advisory Board of Civil Engineering, proposed as a first objective "To link, in the best way possible, and taking advantage of the existing lines, all the capitals of province with the capital of the Monarchy” (Comisión de Ingenieros, 1864, p. 200). The report distinguished between main lines, which could receive financial help from the State, and secondary lines, which would only be granted if there were entrepreneurs willing to undertake their construction without state support. The main lines included all those necessary to complete the connection of the province capitals with Madrid, plus a few non-radial exceptions. The vast majority of transversal connections were proposed as secondary lines (Comisión de Ingenieros, 1864, pp. 201-204 and 208-214). 
A year later, in 1865, a special committee was appointed to assess the effects of the 1855 Act. The building activity induced by public subsidies had been such that the committee judged that the network was far larger than a country with Spain's population, wealth and economic activity actually needed, and that it was unsustainable with the resources available (Mateo del Peral, 1978, p. 101). Map 3 shows the entirety of the network in late 1865.

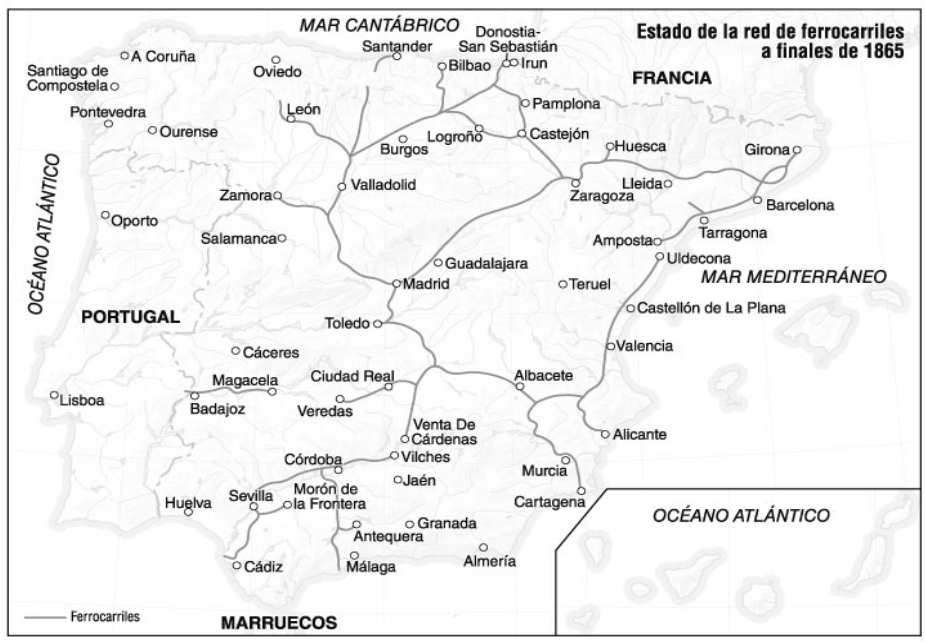

Map 3: Railway network by the end of 1865

The special committee drafted a proposal, completed in 1867, with a double objective. From the perspective of administrative and domestic policy, the proposal aimed to link Madrid to all provincial capitals not yet connected. As far as commerce was concerned, it sought to increase traffic by linking productive and trading areas which had previously been isolated; cross lines carried out their specific function of activating trade between the main export and import areas. Nevertheless, amid growing political and economic instability Isabel II was deposed in 1868, in the wake of what came to be known as the September Revolution.

The new government, though generally more liberal, took a keen interest in the field of public works, especially railways, and in 1870 drafted a bill proposing $2069 \mathrm{~km}$. of new lines. The primary objective was to connect Madrid with all the remaining provincial capitals not covered in the earlier plans (Teruel, Soria, Caceres, Jaen, Almeria, Salamanca, and Pontevedra) or whose licenses were at the risk of expiring before they had even been implemented (Segovia, Cuenca, Huesca, and Huelva). These projects amounted to a total of $1284 \mathrm{~km}$, most of which was to be built in eight years. In addition, another $800 \mathrm{~km}$ of mainly transversal lines were planned, to be built within 20 to 30 years. The government bill became law in 1870. Shortly after the end of the Sexenio Revolucionario and the return of the monarchy, in 1874, a new Act was passed in 1877. It would remain in effect for a long time; according to Mateo del Peral (1979, p. 130) the Act represented "fidelity to the radial pattern 
... with the formulation of lines from Madrid ... It did not solve the problem of the excessive centrality of the network."

In short, railway regulation established the radial, centralized design of the Spanish network. In order to make this possible, the large-scale involvement of the state was needed in the awarding of grants and subsidies. These grants were primarily applied to the radial lines, the ones classified as first order or general service. Financial support from the state was crucial to the success of the construction process, and subsidies became the main fuel of the great investment in railways between 1855 and 1865, ${ }^{7}$ one of the most intense periods of investment in public works in Spain (Alzola y Minondo, 1899, p. 372). The need for subsidies intensified with the construction of lines from the 1870s onwards (Herranz, 2008). In general, state subsidies were essential to support the planned network; its radial, centralized design could not be justified on the grounds of economic or commercial activity.

\section{The establishment and development of motorways in Spain}

\section{The first phase of the (toll) motorways (1960s and 1970s)}

Spain entered the 1960s without intercity motorways. A World Bank report of 1962 recommended the construction of a new motorway along the Mediterranean coast, from France to Murcia. This highway would cross the major industrial, agricultural and tourist areas, the areas with the highest traffic intensity in the country. The report added that increasing traffic would argue in favor of the construction of fast roads in other regions in the near future. Five years after the World Bank Report, in 1967, the Programa de Autopistas Nacionales Españolas (PANE) was drawn up, which foresaw the construction of $3160 \mathrm{~km}$. of toll motorways. In 1972 the first sections were awarded: La Jonquera-Barcelona-Tarragona, and Montgat-Mataró-Bilbao-Behovia. Other concessions followed, such as VillalbaVillacastín-Adanero, Sevilla-Cadiz- and Salou-Valencia-Alicante. The prospect of toll motorways raised great expectations all over the country; the PANE update, the Avance del Plan Nacional de Autopistas of 1972, planned $6430 \mathrm{~km}$. of toll motorways.

In Spain, the funding formula chosen in the 1960s was based on tolls, above all because of the insufficiencies of the country's tax system (Bel, 1999, pp. 124-126). In spite of the initial enthusiasm, however, the direct toll system did not encourage the expansion of the network, and the number of toll motorways in operation advanced very slowly. Of the $6430 \mathrm{~km}$ planned in 1972 and the $2042 \mathrm{~km}$ awarded in 1975, only $1807 \mathrm{~km}$ were working in 1985. Motorway concessions were abruptly terminated during the economic crisis of the 1970s. Map 4 shows the stretches of toll roads operating in the territory.

\footnotetext{
${ }^{7}$ Tortella Casares (1973, pp. 168-173) estimates that public aid represented 49\% of the capital paid out by railway companies until 1867. Researchers believe that it is impossible to evaluate all the subsidies awarded by the state (Comín Comín et al., 1998, p. 93).
} 


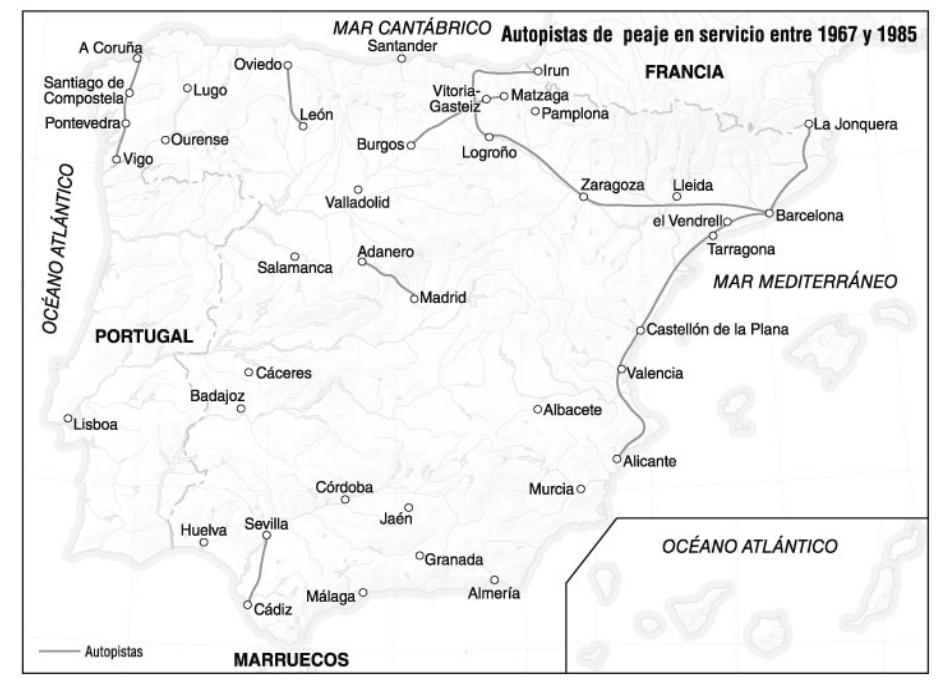

Map 4: Toll motorways built between 1967 and 1985.

It is easy to explain why toll roads were built where they were built. Funding by the user provides incentives to prioritize the routes with more business and growth potential since it offers better prospects for recovering costs. Naturally, the first significant concessions (19671968) were in the corridor with the greatest economic growth and, therefore, the greatest increases in traffic (particularly in goods) and with the highest expectations of profitability. In Spain, these were the stretches between La Jonquera and Tarragona, and between Montgat and Mataró, ${ }^{8}$ that is to say, in the corridor recommended by the World Bank in its report of 1962. In late 1973, the only routes that had been awarded almost entirely were La Jonquera-Alicante and El Vendrell-Bilbao. Indeed, the Mediterranean and the Ebro Valley were the corridors in which economic activity and heavy traffic were growing the fastest, and together they accounted for more than two thirds of the total km of toll motorways. Since they were the most dynamic corridors in terms of both passenger and goods traffic, they offered greater potential for obtaining toll revenues.

\section{From tolls to budged funding: Free motorways in the second phase (1980s-...)}

From the mid-1970s onwards, a series of problems that had emerged in the Spanish toll model began to be debated. Besides the very limited expansion achieved, another point of dissatisfaction with the policy of toll road concessions was the detriment to public finances in the medium and long term.

\footnotetext{
${ }^{8}$ Indeed, these first concessions have been highly profitable (Albalate \& Bel, 2009).
} 
On coming to power in late 1982, the Spanish Socialist Party opted for a model of budgetary financing for the new highways in their General Road Plan (PGC) 1984-1991. ${ }^{9}$ There were several reasons for this change of policy. The two most important were the fact that the tax burden in Spain was much higher than in the 1960s -and so were the available funds from the budget-, and the fact that the country's entry into the EEC and access to European regional policy funds provided additional budgetary resources for the construction of motorways.

The investment budget funding speeded up the provisioning process for highways, and the PGC was completed in 1993. The result was a spectacular extension of the motorway network in Spain. By the end of 1993, 3045 km of PGC-toll-free highways had entered into service. ${ }^{10}$ Map 5 shows the position of the new free highway stretches in the Spanish territory. Significantly, $76 \%$ of the km corresponded to radial highways, while only $24 \%$ were located in the transversal corridors. $^{11}$

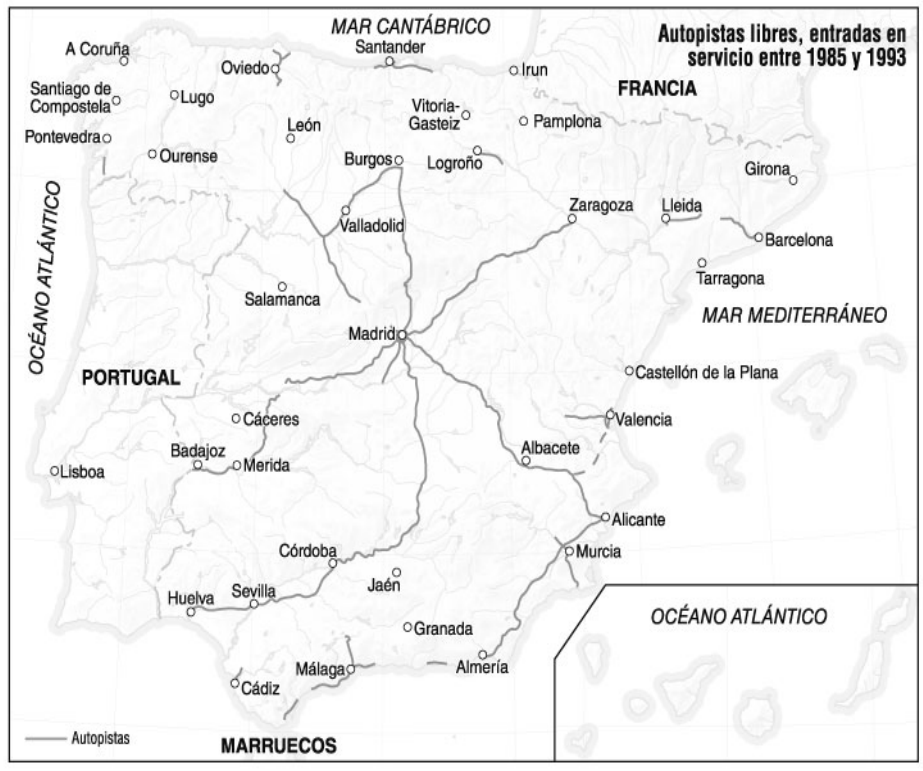

Map 5: Toll-free motorways opened between 1985 and 1993

\footnotetext{
${ }^{9}$ See Boletín Oficial de la Cortes Generales (Congreso de los Diputados), Serie E, n. 160, 1 March 1986, pp. 1853-1882 (p. 1873).

${ }^{10}$ In the same period, well under a hundred km of new toll motorways were franchised by the state.

${ }^{11}$ Detailed information on the routes and years in which stretches of free motorways were opened can be found in Bel (1994).
} 
The effect of the construction of PGC motorways was clearly described by the General Secretary for Surface Transport Infrastructures (Spanish Government), Emilio Pérez Touriño (1994, pp. 14-15): "It is a network that has provided the radiality of our country with high capacity roads... as for the funding of high capacity, the network is focused on completing the radial connections of our country". While some of the radial highways were among the roads with most intense traffic, traffic in other radial highways (i.e. Madrid-Badajoz and BurgosTordesillas) was less intense than that in many transversal routes that were not converted into free motorways (Bel, 2010; pp. 151-154).

In short, highway construction began in the 1960s with the almost exclusive introduction of toll roads in the corridors with higher traffic and toll revenue expectations. In the second stage, the state took on the main role and used the public budget to turn the motorway network into a radial one, prioritizing the radial roads that converge on Madrid. This policy diverged from that in the main European countries; the toll-free motorway extension in Germany was driven by commercial interests from the very beginning (Rothengatter, 2005); other important countries have consistently and continuously used tolls to fund the motorways network all over their territory, as in France (Fayard, Gaeta \& Quinet, 2005) and Italy (Greco \& Ragazzi, 2005). In the Spanish case, the parallelism with the financial pattern followed in the railway extension is very striking. Moreover, it clearly illustrates the existence of an underlying pattern in the country's infrastructure policy, sustained over time, which responds to reasons that have not much to do with transport policy in a strict sense.

\section{Railway modernization from the 'kilometer zero': Implementation and development of the Alta Velocidad Española (AVE)}

The Spanish High Speed Train (AVE, not compatible with freight traffic so far) has become the rising star of the Spanish infrastructure policy. The investment in AVE lines shows the degree of primacy it has enjoyed, with enormous amounts of material resources and technical and human energy being devoted to its extension. According to the Ministry of Public Works' Strategic Plan for Transport Infrastructures, this trend is likely to continue until 2020.

The first AVE line became operational in 1992 between Madrid and Seville, and allows the non-stop journey between the two cities in two hours and 20 minutes. Spain decided to build a segregated high-speed network, as had been done in Japan and France (though in these countries conventional lines are compatible since they share the same gauge), and unlike Germany and Italy. Also unlike other countries, Spain decided to buy rail technology abroad rather than develop its own technology (Vickerman, 1997).

In 1995, the construction of the AVE Madrid-Barcelona-French Border line began, which started to run in 2003 between Madrid and Lleida and reached Tarragona in late 2006. At the end of 2007 the AVE started its services from Madrid to Segovia-Valladolid, and Malaga, in this last case from the line between Madrid and Seville. A branch was also opened from this line to Toledo in 2005. The AVE arrived in Barcelona in February 2008, and almost the entire stretch to the French border is currently in construction. In December 2010, the AVE between Madrid and Valencia has become operational. Spain is now second only to China in terms of operative high-speed kilometers. 
In Spain, the development of the AVE has followed political criteria and has not paid attention to the social return on this investment. The cost-benefit analysis for the MadridSeville line showed that this relationship could not be economically justified given its net negative benefits, and relatively low traffic, despite its large modal share in the corridor (De Rus and Inglada, 1997). A recent analysis of the profitability of the Madrid-Barcelona line showed that potential demand would not offset the large-scale investment, and that time savings would be small in aggregate terms, although it would manage to capture a large share of traffic (De Rus and Roman, 2006).

Indeed, the policy of AVE extension has involved very high investment costs. Overall, cumulative investment until 2010 is close to 45 billion $€$ (Albalate and Bel, 2011), suggesting very low (or negative) rates of return. The total volume of traffic is very low, because the population served is relatively small and the competition from air transport is higher than in other countries, given Spain’s geography and urban structure.

Countries that were pioneers in the development of high-speed networks in Europe (France and Germany) have granted priority to issues such as the potential traffic demand of the lines to modernize, the freight traffic needs, and so on: that is to say, to the core issues of transport policy. In this way, high speed rail extension in France has been restricted to lines generating a positive net social return of investments (Dunn \& Perl, 1994; Vickerman, 1997). In Germany, the main consideration when designing the new lines (mixed passenger-freight) has been serving the highly profitable overnight traffic between the North Sea ports and the industrial areas and consumer markets in Southern Germany (Heinisch, 1992).

The case of Spain is different. The rationale for the extension of the AVE network was expressly declared on April 25, 2000 by the then Prime Minister José María Aznar, who declared the lynchpin of its infrastructure policy "a high-speed rail network that, in ten years, will place all provincial capitals within four hours from the center of the peninsula"(Aznar, 2000, p. 29) - whatever the cost, and regardless of the fundamental function that transport fulfills. So Spain is the country with the most high speed train kilometers in Europe, although its demand for services is very small compared with the pioneers: AVE passengers in Spain account for only about 6\% of those in Japan, about 15\% of those in France, and about $30 \%$ of those in Germany.

Therefore, the development of the AVE, with its radial expansion, has followed a familiar pattern: the use of the law (regulation) and budget subsidies to achieve something that cannot be sustained by economic dynamics, that is, the radialization of Spain's communication networks. It is yet another example of an infrastructure policy that has been in operation since the eighteenth century, more precisely since the enactment, on 23 April 1720, of the Reglamento General para la Dirección y Gobierno de los Oficios de Correo Mayor y Postas de España, en los viajes que se hicieren: the constituent act of the radial state.

\section{Conclusion}

The objective of this paper has been to analyze whether the radial design of surface transportation networks in Spain is due to centralist policies intended to establish territorial control and to maintain a hierarchical government administrative system managed from the capital city, Madrid. To do so, we have explored the infrastructure policy regarding roads and 
railways implemented in Spain between 1720 and 2010. Special emphasis has been placed on the analysis of network regulation and financing used by the national government in order to centralize the road and railway networks.

Our analysis draws attention to a long-term pattern: transportation infrastructure policy in Spain has been driven not by the requirements of commerce and economic activity, but by the desire to centralize the transport system around the country's political capital. Regulation and subsidies from the national budget have regularly been used to decide the priorities, because the development of this policy was not sustainable by commerce alone.

When designing their infrastructure policy, most developed countries have given priority to the requirements of the economic system. Instead, Spain has used that policy for the purposes of nation-building. The contribution of the transport system to productivity and efficiency has been systematically disregarded as a driver for infrastructure policy. The territorial asymmetries in toll versus non-toll motorways and overinvestment in national networks such as High Speed Rail can be explained within the framework of a philosophy that goes back three hundred years. 


\section{References}

Albalate, D. \& Bel, G. (2009). Regulating Concessions of Toll Motorways: An Empirical Study on Fixed vs. Variable Term Contracts. Transportation Research-A, 43, 219 -229.

Albalate, D. \& Bel, G. (2011). Cuando la economía no importa: Auge y esplendor de la alta velocidad en España. Revista de Economía Aplicada, forthcoming.

Álvarez Junco, J. (2001). Mater Dolorosa. La idea de España en el siglo XIX. Madrid: Taurus.

Alzola y Minondo, P. (1899). Las obras públicas en España: Estudio histórico. Bilbao: Biblioteca de la Revista de Obras Públicas.

Aznar, J.M. (2000). Debate sobre la investidura del candidato a la Presidencia del Gobierno. Diario de Sesiones del Congreso de los Diputados. Pleno y Diputación Permanente. Año 2000, nº 2 (25 April 2000).

Banco Mundial (1962). Informe del Banco Mundial. El desarrollo económico de España. Madrid: BIRF.

Bel, G. (1994). La demanda de transporte en España: Competencia intermodal sobre el ferrocarril interurbano. Madrid: IETC.

Bel, G. (1999). Financiación de infraestructuras viarias: La economía política de los peajes. Papeles de Economía Española, 82, 123-139

Bel, G. (2010). España, capital París. Origen y apoteosis del Estado radial. Barcelona: Destino.

Caron, F. (1983). France. In Patrick O’Brien, Railways and the economic development of Western Europe, 1830-1914 (pp. 28-48). London: MacMillan.

Casañas Vallés, M. (1977). El ferrocarril en España, 1844-1868. Consideraciones en torno a una crisis. Investigaciones Económicas, 4, 39-68.

Comín Comín, F., Martín Aceña, P., Muñoz Rubio, M. \& Vidal Olivares, J. (1998). 150 años de historia de los ferrocarriles españoles. Volumen I. Madrid: Anaya.

Comisión de ingenieros (1864). Ante-proyectos del Plan General de Ferro-carriles. Memoria. Revista de Obras Públicas, 12, 198-204 \& 208-215.

Congreso de los Diputados. (1850). Información parlamentaria hecha por la Comisión de Ferrocarriles nombrada por el Congreso de los Diputados en 10 de enero de 1850. Madrid: Imprenta Nacional.

De Diego García, E. (1983). El ferrocarril: La Habana-Güines. Cuadernos de Historia Moderna y Contemporánea, 4, 59-77.

De Riquer, B. (1994). Aproximación al nacionalismo español contemporáneo. Studia Historica. Historia Contemporánea, 12, 11-29.

De Rus, G. \& Inglada, V. (1997). Cost-benefit analysis of the high-speed train in Spain. Annals of Regional Science, 31, 175-188.

De Rus, G.\& Román, C. (2006). Análisis económico de la línea de alta velocidad Madrid-Barcelona. Revista de Economía Aplicada, 14, 35-80.

Derry, T.K. \& Williams, T.I. (1960). A short history of technology from the earliest times to A.D. 1900. Oxford: Clarendon Press.

Docwra, G.E.\& Kolsen, H.M. (1989). Transport and Australian federalism, 1901-1972. Journal of Transport History, 10, 59-73.

Dunham, A.L. (1941). How the first French railways were planned. Journal of Economic History, 1, 12-25.

Dunn, J. \& Perl, A. (1994). Policy networks and industrial revitalization: High Speed Rail initiatives in France and Germany. Journal of Public Policy, 14, 311-343.

Elliot, J.H. (1963). Imperial Spain. London: Edward Arnold Publishers.

Fayard, A., Gaeta, F. \& Quinet, E. (2005). French motorways: Experience and assessment. Research in Transportation Economics, 15, 93-105.

Fenoaltea S. (1983). Italy. In Patrick O’Brien, Railways and the economic development of Western Europe, 1830-1914 (pp. 49-121). London: MacMillan.

Fernandez de Mesa, T.M. (1755). Tratado legal y político de caminos públicos y possadas. Valencia: Joseph Thomàs Lucas en la Plaza de las Comedias.

Fleming, F.J. (1991). Profits and visions: British capital and railway construction in Argentina, 18541886. In C.B. Davis, K.E. Wilburn \& R.E. Robinson (Eds.) Railway Imperialism (pp. 71-84). New York: Greenwood Press. 
Flichy, P. (1995). Dynamics of Modern Communication. The Shaping and Impact of New Communication Technologies. London: Sage $\left(1^{\text {st }}\right.$ ed. in French, Paris: Éditions La Découverte, 1991)

Fremlindg, R. (1983). Germany. In Patrick O’Brien, Railways and the economic development of Western Europe, 1830-1914 (pp. 121-148). London: MacMillan.

Gómez Mendoza, A. (2001). Madrid, centro de la red de comunicaciones. Arbor, 169, 343-358.

Gray, I. (2009). Maintaining the power of central governments: Regional land transport in the Australian Federation, 1850-2007. Journal of Transport History, 30, 22-39.

Greco, A. \& Ragazzi, G. (2005). History and regulations of Italian highways concessionaires. Research in Transportation Economics, 15, 121-133.

Hawke, G. \& Higgins, J. (1983). Britain. In Patrick O’Brien, Railways and the economic development of Western Europe, 1830-1914 (pp. 170-202). London: MacMillan.

Heinisch, R. (1992). High Speed Trains in Germany. Rail International, 23, $23-24$.

Herranz Loncán, A. (2008). Infraestructuras y crecimiento económico en España (1850-1935). Madrid: Fundación de los Ferrocarriles Españoles.

Lluch, E. (1996). La Catalunya vençuda del segle XVIII. Foscors i clarors de la II·lustració. Barcelona: Edicions 62.

Mateo del Peral, D. (1978). Los orígenes de la política ferroviaria en Espala (1844-1877). In M. Artola (dir.), R. Cordero, D. Mateo y F. Menéndez, Los ferrocarriles en España 1844/1943. Tomo I. El Estado y los ferrocarriles (pp. 31-159). Madrid: Servicio de Estudios del Banco de España.

Menéndez Pidal, G. (1951). Los caminos en la Historia de España. Madrid: Ediciones Cultura Hispánica.

Nadal, J. (1975). El fracaso de la revolución industrial en España. 1814-1913. Barcelona: Ariel.

Pascual Domènech, P. (1999). Los caminos de la era industrial. La construcción y financiación de la Red Ferroviaria Catalana (1843-1898). Barcelona: Edicions de la Universitat de Barcelona.

Pérez Touriño, E. (1994). Efectos del Plan. Realizaciones y balance socioeconómico. Estudios de Transporte y Comunicaciones, 65 (separata), 9-27.

Ringrose, D.R. (1994). Madrid, capital imperial (1561-1833). In S. Juliá, D. Ringrose \& C. Segura, Madrid. Historia de una capital (pp. 153-314). Madrid: Alianza Editorial, 1994 (ed. 2000).

Ringrose, D.R. (1996). España, 1700-1900: el mito del fracaso. Madrid: Alianza Editorial.

Rothengatter, W. (2005). Motorways and motorway finance in Germany and Austria. Research in Transportation Economics, 15, 75-91.

Smith, A. (1776). The Wealth of Nations (3rd. edition, London: W. Strahan y T. Cadell, 1784).

Tortella Casares, G. (1973). Los Orígenes del capitalismo en España: Banca, industria y ferrocarriles en el siglo XIX. Madrid: Tecnos.

Uriol, J.I. (1977). Los viajes por la posta en el siglo XVIII y en los primeros años del siglo XIX. Revista de Obras Públicas, 124, 837-856.

Uriol, J.I. (1978). Las carreteras y los canales de navegación en los reinados de Fernando VI y Carlos III. Revista de Obras Públicas, 125, 533-546.

Uriol, J.I. (1985). Las calzadas romanas y los caminos del siglo XVI. Revista de Obras Públicas, 132, 553-563.

Vicens Vives, J. (1952). Aproximación a la Historia de España. Barcelona: Vicens Vives.

Vickerman, R. (1997). High-speed rail in Europe: experience and issues for future development. Annals of Regional Science, 31, 21-38.

Villuga, J. (1546). Repertorio de caminos. Medina del Campo.

Ward, B. (1762). Proyecto Económico, en el que se proponen varias providencias, dirigidas a promover los intereses de España, con los fondos y medios necesarios para su plantificación. Madrid: D. Joachín Ibarra, Impresor de Cámara de S.M. (second edition, 1779)

Wotherspoon, G. (1979). The determinants of the pattern and pace of railway development in New South Wales, 1850-1914. Australian Journal of Politics \& History, 25, 51-65.

\section{Official publications}

Olozaga's Commission (Spanish Congress, 1850). Minutes of testimonies made in the Commission. Spanish Congress Gazette. Spanish Official Gazette.Endnotes 
WP 2010/16

WP 2010/15

WP 2010/14

WP 2010/13

WP 2010/12

WP 2010/11

WP 2010/10

WP 2010/09

WP 2010/08

WP 2010/07

WP 2010/06

WP 2010/05

WP 2010/04

WP 2010/03

WP 2010/02

WP 2010/01

WP 2009/26

WP 2009/25

WP 2009/24

WP 2009/23

WP 2009/22

WP 2009/21

WP 2009/20

WP 2009/19

WP 2009/18

WP 2009/17
"Infrastructure and nation building: The regulation and financing of network transportation infrastructures in Spain (1720-2010)”Bel,G

"Fiscal policy and economic stability: does PIGS stand for Procyclicality In Government Spending?" Maravalle, A ; Claeys, P.

"Economic and social convergence in Colombia” Royuela, V; Adolfo García, G.

“ Symmetric or asymmetric gasoline prices? A meta-analysis approach” Perdiguero, J.

“ Ownership, Incentives and Hospitals” Fageda,X and Fiz, E.

"Prediction of the economic cost of individual long-term care in the Spanish population” Bolancé, C ; Alemany, R ; and Guillén M

“On the Dynamics of Exports and FDI: The Spanish Internationalization Process” Martínez-Martín $\mathrm{J}$.

"Urban transport governance reform in Barcelona” Albalate, D ; Bel, G and Calzada, J.

“Cómo (no) adaptar una asignatura al EEES: Lecciones desde la experiencia comparada en España” Florido C. ; Jiménez JL. and Perdiguero J.

"Price rivalry in airline markets: A study of a successful strategy of a network carrier against a low-cost carrier” Fageda, X ; Jiménez J.L. ; Perdiguero , J.

"La reforma de la contratación en el mercado de trabajo: entre la flexibilidad y la seguridad" Royuela V. and Manuel Sanchis M.

"Discrete distributions when modeling the disability severity score of motor victims" Boucher, J and Santolino, $\mathrm{M}$

"Does privatization spur regulation? Evidence from the regulatory reform of European airports . Bel, G. and Fageda, X.”

“High-Speed Rail: Lessons for Policy Makers from Experiences Abroad”. Albalate, D ; and Bel, G.”

“Speed limit laws in America: Economics, politics and geography”. Albalate, D ; and Bel, G.”

“Research Networks and Inventors’ Mobility as Drivers of Innovation: Evidence from Europe” Miguélez, E. ; Moreno, R. ”

"Social Preferences and Transport Policy: The case of US speed limits" Albalate, D.

”Human Capital Spillovers Productivity and Regional Convergence in Spain”, Ramos, R ; Artis, M. ; Suriñach, J.

“Human Capital and Regional Wage Gaps”,López-Bazo,E. Motellón E.

“Is Private Production of Public Services Cheaper than Public Production? A meta-regression analysis of solid waste and water services” Bel, G.; Fageda, X.; Warner. M.E.

“Institutional Determinants of Military Spending” Bel, G., Elias-Moreno, F.

“Fiscal Regime Shifts in Portugal” Afonso, A., Claeys, P., Sousa, R.M.

"Health care utilization among immigrants and native-born populations in 11 European countries. Results from the Survey of Health, Ageing and Retirement in Europe” Solé-Auró, A., Guillén, M., Crimmins, E.M.

"La efectividad de las políticas activas de mercado de trabajo para luchar contra el paro. La experiencia de Cataluña” Ramos, R., Suriñach, J., Artís, M.

“Is the Wage Curve Formal or Informal? Evidence for Colombia” Ramos, R., Duque, J.C., Suriñach, J.

“General Equilibrium Long-Run Determinants for Spanish FDI: A Spatial Panel Data Approach” Martínez-Martín, J. 
WP 2009/16

WP 2009/15

WP 2009/14

WP 2009/13

WP 2009/12

WP 2009/11

WP 2009/10

WP 2009/09

WP 2009/08

WP 2009/07

WP 2009/06

WP 2009/05

WP 2009/04

WP 2009/03

WP 2009/02

WP 2009/01

WP 2008/16

WP 2008/15

WP 2008/14

WP 2008/13

WP 2008/12

WP 2008/11

WP 2008/10

WP 2008/09

WP 2008/08
“Scientists on the move: tracing scientists' mobility and its spatial distribution” Miguélez, E.; Moreno, R.; Suriñach, J.

“The First Privatization Policy in a Democracy: Selling State-Owned Enterprises in 1948-1950 Puerto Rico” Bel, G.

“Appropriate IPRs, Human Capital Composition and Economic Growth” Manca, F.

“Human Capital Composition and Economic Growth at a Regional Level” Manca, F.

“Technology Catching-up and the Role of Institutions” Manca, F.

“A missing spatial link in institutional quality” Claeys, P.; Manca, F.

“Tourism and Exports as a means of Growth” Cortés-Jiménez, I.; Pulina, M.; Riera i Prunera, C.; Artís, M.

“Evidence on the role of ownership structure on firms' innovative performance” Ortega-Argilés, R.; Moreno, R.

“¿Por qué se privatizan servicios en los municipios (pequeños)? Evidencia empírica sobre residuos sólidos y agua” Bel, G.; Fageda, X.; Mur, M.

“Empirical analysis of solid management waste costs: Some evidence from Galicia, Spain” Bel, G.; Fageda, X.

“Intercontinental fligths from European Airports: Towards hub concentration or not?” Bel, G.; Fageda, X.

"Factors explaining urban transport systems in large European cities: A cross-sectional approach" Albalate, D.; Bel, G.

"Regional economic growth and human capital: the role of overeducation" J.; Artís, M.

“Regional heterogeneity in wage distributions. Evidence from Spain” Motellón, E.; López-Bazo, E.; El-Attar, $\mathrm{M}$.

"Modelling the disability severity score in motor insurance claims: an application to the Spanish case” Santolino, M.; Boucher, J.P.

“Quality in work and aggregate productivity” Royuela, V.; Suriñach, J.

"Intermunicipal cooperation and privatization of solid waste services among small municipalities in Spain” Bel, G.; Mur, M.

"Similar problems, different solutions: Comparing refuse collection in the Netherlands and Spain" Bel, G.; Dijkgraaf, E.; Fageda, X.; Gradus, R.

"Determinants of the decision to appeal against motor bodily injury settlements awarded by Spanish trial courts” Santolino, M

"Does social capital reinforce technological inputs in the creation of knowledge? Evidence from the Spanish regions” Miguélez, E.; Moreno, R.; Artís, M.

“Testing the FTPL across government tiers” Claeys, P.; Ramos, R.; Suriñach, J.

“Internet Banking in Europe: a comparative analysis” Arnaboldi, F.; Claeys, P.

"Fiscal policy and interest rates: the role of financial and economic integration” Claeys, P.; Moreno, R.; Suriñach, J.

“Health of Immigrants in European countries” Solé-Auró, A.; M.Crimmins, E.

“The Role of Firm Size in Training Provision Decisions: evidence from Spain” Castany, L. 
WP 2008/07 "Forecasting the maximum compensation offer in the automobile BI claims negotiation process" Ayuso, M.; Santolino, M.

WP 2008/06 "Prediction of individual automobile RBNS claim reserves in the context of Solvency II” Ayuso, M.; Santolino, M.

WP 2008/05 “Panel Data Stochastic Convergence Analysis of the Mexican Regions” Carrion-i-Silvestre, J.L.; German-Soto, V.

WP 2008/04 "Local privatization, intermunicipal cooperation, transaction costs and political interests: Evidence from Spain” Bel, G.; Fageda, X.

WP 2008/03 “Choosing hybrid organizations for local services delivery: An empirical analysis of partial privatization” Bel, G.; Fageda, X.

WP 2008/02 “Motorways, tolls and road safety. Evidence from European Panel Data” Albalate, D.; Bel, G.

WP 2008/01 “Shaping urban traffic patterns through congestion charging: What factors drive success or failure?” Albalate, D.; Bel, G.

WP 2007/19 “La distribución regional de la temporalidad en España. Análisis de sus determinantes” Motellón, E.

WP 2007/18 “Regional returns to physical capital: are they conditioned by educational attainment?” López-Bazo, E.; Moreno, R.

WP 2007/17 "Does human capital stimulate investment in physical capital? evidence from a cost system framework” López-Bazo, E.; Moreno, R.

WP 2007/16 “Do innovation and human capital explain the productivity gap between small and large firms?” Castany, L.; López-Bazo, E.; Moreno, R.

WP 2007/15 “Estimating the effects of fiscal policy under the budget constraint” Claeys, P.

WP 2007/14 "Fiscal sustainability across government tiers: an assessment of soft budget constraints” Claeys, P.; Ramos, R.; Suriñach, J.

WP 2007/13 "The institutional vs. the academic definition of the quality of work life. What is the focus of the European Commission?” Royuela, V.; López-Tamayo, J.; Suriñach, J.

WP 2007/12 “Cambios en la distribución salarial en españa, 1995-2002. Efectos a través del tipo de contrato” Motellón, E.; López-Bazo, E.; El-Attar, M.

WP 2007/11 “EU-15 sovereign governments’ cost of borrowing after seven years of monetary union” GómezPuig, M..

WP 2007/10 Another Look at the Null of Stationary Real Exchange Rates: Panel Data with Structural Breaks and Cross-section Dependence” Syed A. Basher; Carrion-i-Silvestre, J.L.

WP 2007/09 "Multicointegration, polynomial cointegration and I(2) cointegration with structural breaks. An application to the sustainability of the US external deficit” Berenguer-Rico, V.; Carrion-i-Silvestre, J.L.

WP 2007/08 "Has concentration evolved similarly in manufacturing and services? A sensitivity analysis” RuizValenzuela, J.; Moreno-Serrano, R.; Vaya-Valcarce, E.

WP 2007/07 "Defining housing market areas using commuting and migration algorithms. Catalonia (Spain) as an applied case study” Royuela, C.; Vargas, M.

WP 2007/06 "Regulating Concessions of Toll Motorways, An Empirical Study on Fixed vs. Variable Term Contracts” Albalate, D.; Bel, G.

WP 2007/05 “Decomposing differences in total factor productivity across firm size” Castany, L.; Lopez-Bazo, E.; Moreno, R.

WP 2007/04 “Privatization and Regulation of Toll Motorways in Europe” Albalate, D.; Bel, G.; Fageda, X. 
WP 2007/03 "Is the influence of quality of life on urban growth non-stationary in space? A case study of Barcelona” Royuela, V.; Moreno, R.; Vayá, E.

WP 2007/02 “Sustainability of EU fiscal policies. A panel test” Claeys, P.

WP 2007/01 "Research networks and scientific production in Economics: The recent spanish experience” Duque, J.C.; Ramos, R.; Royuela, V.

WP 2006/10 “Term structure of interest rate. European financial integration” Fontanals-Albiol, H.; Ruiz-Dotras, E.; Bolancé-Losilla, C.

WP 2006/09 "Patrones de publicación internacional (ssci) de los autores afiliados a universidades españolas, en el ámbito económico-empresarial (1994-2004)” Suriñach, J.; Duque, J.C.; Royuela, V.

WP 2006/08 “Supervised regionalization methods: A survey” Duque, J.C.; Ramos, R.; Suriñach, J.

WP 2006/07 “Against the mainstream: nazi privatization in 1930s germany” Bel, G.

WP 2006/06 “Economía Urbana y Calidad de Vida. Una revisión del estado del conocimiento en España” Royuela, V.; Lambiri, D.; Biagi, B.

WP 2006/05 “Calculation of the variance in surveys of the economic climate” Alcañiz, M.; Costa, A.; Guillén, M.; Luna, C.; Rovira, C.

WP 2006/04 "Time-varying effects when analysing customer lifetime duration: application to the insurance market” Guillen, M.; Nielsen, J.P.; Scheike, T.; Perez-Marin, A.M.

WP 2006/03 “Lowering blood alcohol content levels to save lives the european experience” Albalate, D.

WP 2006/02 "An analysis of the determinants in economics and business publications by spanish universities between 1994 and 2004” Ramos, R.; Royuela, V.; Suriñach, J.

WP 2006/01 “Job losses, outsourcing and relocation: empirical evidence using microdata” Artís, M.; Ramos, R.; Suriñach, J. 
$\mathbb{\Phi}_{\mathbb{Q}}|\mathrm{R}| \mathrm{E}|\mathrm{A}|$ 